\title{
The omicron hodge-podge: Travel bans, vaccine mandates, children and vaccine equity
}

As of 3 December 2021, there were 263563622 confirmed cases of COVID19 , and 5232562 COVID deaths globally. At this stage, 7864123038 vaccine doses had been administered worldwide. ${ }^{[1]}$ The discovery of the omicron variant announced by South African (SA) scientists on 25 November $^{[2]}$ was followed by an exponential increase in COVID-19 cases in the country, and SA was officially declared to be in the fourth wave at the beginning of December. At this stage, population-level evidence suggests that the omicron variant is associated with substantial ability to evade immunity from prior infection, but questions remain as to whether it is also able to evade vaccine-induced immunity. ${ }^{[3]}$ More has yet to be determined by in vitro and in vivo evidence. ${ }^{[2]}$ While there is some understanding of omicron and its effects, much uncertainty remains.

Southern Africa witnessed a backlash for the honest and transparent communication from SA scientists, with the UK immediately imposing a ban on travel from the region. Several other countries promptly followed suit. ${ }^{[2]}$ Discussion continued as to whether travel restrictions are irrational, unscientific and knee-jerk in nature. With the variant being found in close to 50 nations worldwide, it is blatantly clear that travel restrictions have not stopped the spread of the virus. Without doubt, though, the restrictions have resulted in enormous damage. Public health ethics and the collective good demand swift, candid and truthful transmission of scientific information when this is necessary for the protection of population health. In the context of pandemics, this would be for the protection of global health. Instead of evoking a concerted and systematic effort by countries around the globe on the best way forward to address the problem of ongoing mutations and variants evolving, the morally correct engagement by the scientists on the discovery of omicron resulted in southern Africa being shunned, discriminated against and stigmatised by many parts of the world. In addition to the economic setbacks and other social harms that follow, the damage done to transparent and expeditious scientific communication could be far-reaching.

Omicron heightened discussions in SA on mandatory vaccinations, banning of mass gatherings and rage parties and how to improve confidence in the COVID-19 vaccine. Initially, deliberations on compulsory vaccinations started with implementing such mandates in the workplace, after the Direction that was gazetted by the Minister of Labour, ${ }^{[4]}$ and went on to the fairness of requiring vaccine certificates to be produced at recreational facilities and similar spaces. By the end of October, Universities of South Africa (USAf), SA's 26-member vice-chancellors' body, had declared that COVID-19 vaccinations were necessary at tertiary institutions. Several universities have moved forward on this, and proof of vaccination or a recent negative SARS-CoV-2 test as a condition for entry onto university premises are planned for implementation in January 2022. With rapidly rising SARS-CoV-2 positive tests soon after the discovery of omicron, a task team was convened by the government to consult with stakeholders on mandatory vaccinations. ${ }^{[5]}$

More recently, the introduction of vaccine mandates in secondary schools has been mooted. ${ }^{[6]}$ Despite the SA Health Products Regulatory Authority (SAHPRA) approving the use of the Pfizer vaccine for children $\geq 12$ years on 10 September $2021,{ }^{[7]}$ and the government subsequently opening COVID-19 vaccinations for children in this age group ${ }_{,}^{[8]}$ uptake among these children has been quite low. Vaccination in the adult $<50$-year group has been slow. Presumably, parents who are hesitant to vaccinate will not encourage their children to do so. In addition, open condemnation of COVID-19 vaccines by some healthcare workers adds to the uncertainties of people who are vaccine hesitant, and further erodes vaccine confidence. To compound the problems, the African Christian Democratic Party (ACDP), supported by some organisations, applied for an interdict to stop the rollout of COVID-19 vaccinations to children. The Pretoria High Court ruled that the application was not urgent and that it could be heard at a later stage. ${ }^{[9]}$ With the advent of omicron, the age category has evolved to include younger adults and children becoming ill and being hospitalised. Severity still remains highest among the unvaccinated. It has been reported that according to the National Institute of Communicable Diseases, infections among younger children and hospital admissions of under-5-year-olds are on the increase. ${ }^{[10]}$ In the USA, the Centers for Disease Control and Prevention (CDC) has already issued approval for COVID-19 vaccinations in adjusted doses for children 5 - 11 years old after scientists conducted clinical trials with about 3000 children. The CDC advises that children between 2 and 4 years old continue to wear masks in public spaces. ${ }^{[11]}$ The principle of vulnerability in health research requires that trials are conducted in the less vulnerable prior to advancing to include the more vulnerable. This explains why adults are enrolled in research before children. However, this principle could at times be a double-edged sword, in that children may be excluded from essential research or from receiving critical interventions because of the long waits before research is allowed to be conducted in this vulnerable group. With the changing demographics by age category of COVID-19 infections, it may be prudent to consider including the $<12$-year-old group in the national roll-out programme at some stage. Nevertheless, this would need to be conditional to equity considerations.

While we lament the lack of equitable access to vaccines, the selfishness of high-income countries and the greed of big pharma as reasons for this rapid evolution of variants, we need to reflect on what else may be contributing to the problem. Namibia has started to destroy expired vaccines because of slow uptake, ${ }^{[12]}$ and SA has halted its vaccine delivery for the same reason. ${ }^{[13]}$ There is urgency to building vaccine confidence in our communities - if not, we will continue to compete with the virus and perhaps even be defeated by this invisible enemy, which has thus far managed to evade efforts at suppression. The vaccine narrative started with the trajectory being that of achieving herd immunity. As the variants evolved, herd immunity seemed to grow into an illusion. Eradication of the virus may not be possible, especially as the virus is evolving in ways that we are unable to control. One thing that we can control in this fight between man and virus is our behaviour. If all of us conduct ourselves responsibly, wear our masks, avoid mass gatherings and vaccinate, we can defeat the virus. In this struggle, responsibilities must be shared by all, and not left to certain sectors only.

\section{Ames Dhai}

Editor-in-Chief

ames.dhai@wits.ac.za 
S Afr J Bioethics Law 2021;14(3):75-76. https://doi.org/10.7196/ SAJBL.2021.v1431.794

1. World Health Organization. Coronavirus (COVID-19) Dashboard. WHO, 2021. https:// covid19.who.int/ (accessed 3 December 2021).

2. Mendelson M, Venter F, Moshabela M, et al. The political theatre of the UK's travel ban on South Africa. Lancet 3 December 2021(epub ahead of print). https://doi. org/10.1016/ S0140-6736(21)02752-5

3. Pulliam JRC, van Schalkwyk C, Govender N, et al. Increased risk of SARS-CoV-2 reinfection associated with emergence of the Omicron variant in South Africa. MedRxiv 2 December 2021 (pre-print). https://doi.org/10.1101/2021.11.11.21266068

4. South Africa. Consolidated direction on occupational health and safety measures in certain workplaces. SA Government Gazette No. R. 499. https://www.gov.za/ sites/default/files/gcis document/202106/44700reg11292gon499.pdf (accessed 31 July 2021)

5. Business to approach Constitutional Court over vaccine mandates in South Africa. BUSINESSTECH， 7 December 2021. https://businesstech.co.za/news/ business/544644/business-to-approach-constitutional-court-over-vaccinemandates-in-south-africa/ (accessed 8 December 2021).

6. BUSINESSTECH. Meetings to discuss mandatory vaccinations at schools. BUSINESSTECH, 6 December 2021. https://businesstech.co.za/news/lifestyle/544420/ meetings-to-discuss-mandatory-vaccines-at-schools-in-south-africa-report/ (accessed 6 December 2021).
7. South African Health Products Regulatory Authority. SAHPRA update on section 21 authorisation for Pfizer Comirnaty vaccine. https://www.sahpra.org.za/pressreleases/sahpra-update-on-section-21-authorisation-for-pfizer-comirnatyvaccine/ (accessed 3 December 2021).

8. Phaahla MJ. Minister Joe Phaahla: Coronavirus COVID-19 vaccination rollout programme media briefing. https://www.gov.za/speeches/minister-joe phaahla-covid-19-vaccination-roll-out-programme-media-briefing-15-oct-2021 (accessed 3 December 2021).

9. Ellis E. Court deals blow to ACDP bid to stop Covid-19 vaccination for children. Daily Maverick 12 November 2021. https://www.dailymaverick.co.za/article/2021-1112-court-deals-blow-to-acdp-bid-to-stop-covid-19-vaccinations-for-children/ (accessed 3 December 2021).

10. ENCA COVID-19 in SA: Under-fives hospitalised. ENCA, 3 December 2021. https:// www.enca.com/news/children-may-be-hospitalised-precaution-public-healthspecialist (accessed 3 December 2021).

11. Centers for Disease Control and Prevention. COVID-19 vaccination for children 5 - 11 years old. CDC, 3 December 2021. https://www.cdc.gov/coronavirus/2019-ncov/ vaccines/recommendations/children-teens.html (accessed 3 December 2021).

12. BusinessDay. Namibia to destroy Covid vaccines amid slow uptake. BusinessDay, 25 November 2021. https://www.businesslive.co.za/bd/world/africa/2021-11-25namibia-to-destroy-covid-vaccines-amid-slow-uptake/ (accessed 3 December 2021).

13. Reuters. South Africa delays Covid-19 vaccine deliveries because it has too much stock. Reuters, 24 November 2021. https://www.news24.com/news24/ southafrica/news/south-africa-delays-covid-19-vaccine-deliveries-because-ithas-too-much-stock-20211124 (accessed 3 December 2021). 